Estática e fascismo: sobre a formação dos golpes na América Latina

Revista Ensaios, vol. 13, jul-dez de 2018. ISSN 2175-0564.

\title{
Estética e fascismo: sobre a formação dos golpes na América Latina
}

\author{
Felipe Vieira Britto ${ }^{1}$
}

\begin{abstract}
Resumo: A América Latina experimentou, desde a eleição de Hugo Chávez em 1998, uma onda esmagadora de movimentos progressistas que elegeram governos de esquerda em vários de seus países. Esta onda atraiu os olhares e as movimentações golpistas do maior prejudicado por ela, o imperialismo, que sofisticou e renovou seu antigo método de golpes no terceiro mundo, transformando-os num processo que expressa a relação íntima entre estética e política. Procura-se, no presente artigo, em um primeiro momento, apresentar e relacionar as noções de estética do fascismo e concepção da historiografia burguesa, em Walter Benjamin, e, em um segundo momento, investigar a cronologia do processo de estetização da atividade política que culminou na execução de quase todos os golpes de Estado na América Latina. A demonstração alcançada com esta análise, expressa no último momento, é a de que o processo de ascensão das tendências fascistas resultantes do neogolpismo em todo o continente não se estabeleceram no minuto seguinte aos golpes; antes disso, já se formavam através de uma construção estética elaborada, principalmente, pelo papel dos meios de comunicação de massas nesta nova forma de golpismo.
\end{abstract}

Palavras-chave: Walter Benjamin; estética; fascismo; golpe; América Latina; política.

\section{Aesthetics and fascism: on the formation of the coups in Latin America}

\begin{abstract}
Latin America has experienced, since the election of Hugo Chavez in 1998, an overwhelming wave of progressive movements that have elected left wing governments in several of their countries. This wave attracted the glances and the coup movements of the most impaired by it, imperialism, which sophisticated and renewed its old methodologies of regime change in the third world, transforming them in a process that expresses the intimate relation between aesthetics and politics. The present article first seeks to establish and relate the notions of aesthetics of fascism and the conception of bourgeois historiography in Walter Benjamin's work and, secondly, to investigate the chronology behindthe formation of the process characterized by the aesthetization of the political activity which culminated in the execution of almost all coups d'état in Latin America
\end{abstract}

Keywords: Walter Benjamin; aesthetics; fascism; coup d'état; Latin America; politics.

${ }^{1}$ Universidade Federal Fluminense (UFF), Graduação em Filosofia, Niterói, RJ, Brasil.
felipevieirarj1996@gmail.com. 
Estática e fascismo: sobre a formação dos golpes na América Latina

Revista Ensaios, vol. 13, jul-dez de 2018. ISSN 2175-0564.

É imprescindível, se o objetivo for estabelecer uma tradição histórica e política resistente às movimentações neogolpistas na América Latina, constituir uma análise concreta do processo pelo qual passaram os cenários políticos em que estas movimentações aconteceram. Não obstante, é necessário também compreender que a articulação entre passado e presente é a via que deve tomar a movimentação de resistência.

Ao analisar todos os processos de golpes e tentativas de golpes de Estado na América Latina, bem como o avanço de uma nova corrente política peculiar, o neofascismo, é comum que se negligencie dois pontos fundamentais: 1) ignora-se, em todos os âmbitos, a dimensão estética do problema; 2) toma-se os objetos de análise individualmente, e não pelo conjunto do todo - seja analisando um processo de um país específico isolado dos outros, seja analisando, mesmo em um processo de um país específico, aspectos deste processo individualmente.

Tal abordagem pode ser eficaz para compreender aspectos específicos destas movimentações, como o seu funcionamento mecânico, mas uma abordagem que se pretende a compreender os fundamentos concretos destes eventos precisa necessariamente se questionar em duas linhas: primeiro, se por acaso se trata de um caso isolado em um único país; segundo, se existe coordenação uniforme entre os elementos constitutivos deste caso. Para as duas indagações, a resposta é o contrário do que a abordagem tradicional defende: respectivamente, não e sim.

Há pelo menos três características destas movimentações, em todas as experiências que se deixaram ser observadas: a primeira é o elementar papel dos veículos de comunicação de massas, a segunda é o funcionamento coordenado de aparatos específicos institucionais do Estado - em especial os serviços de inteligência, as cortes e os órgãos de denúncia e apuração - de maneira a dar sustento a uma narrativa de combate à corrupção; a terceira, que é a consequência direta destas duas primeiras, é o avanço significativo e crescente de tendências fascistas. 
Estática e fascismo: sobre a formação dos golpes na América Latina

Revista Ensaios, vol. 13, jul-dez de 2018. ISSN 2175-0564.

Pereira da Silva (2018) supõe que o desenvolvimento desta nova forma de golpismo é precedido pelo menos, por dois importantes fatores, a saber: a relação íntima entre a concepção eurocêntrica e datada do conceito de "democracia" como um conjunto de normas e procedimentos que devem ser replicados em todo o mundo, independente das condições particulares de cada região, e a capacidade que as esquerdas latino-americanas lograram de vencer consecutivas eleições pelo voto popular, uma vez que surgiram num contexto de profunda desigualdade social, política e econômica e conseguiram concretizar projetos de redução da miséria, distribuição de renda e participação política. Como coloca o autor:

Em realidades de profunda desigualdade de renda e de suas demais formas, e se essas democracias funcionam de forma mínima, é de se supor que as forças de esquerda têm condições de chegar ao governo e mantê-lo seguidas vezes, constituindo provavelmente alternativas de poder mais viáveis na maior parte do tempo em comparação com as lideranças e partidos à direita do espectro político. (...)

A estabilidade e a institucionalização de parâmetros mínimos do que é democracia dentro da concepção hegemônica de democracia produziram uma sensação de segurança que se mostrou equivocada. Diversos regimes latino-americanos passaram por recentes rupturas democráticas. (...) Deve-se insistir então que essas são modalidades de "neogolpismo" para marcar suas diferenças com o padrão anterior do subcontinente, também se poderia defini-las mais precisamente como golpes "institucionais", dado seu processamento por meio das instituições vigentes. Talvez essa insistência nas instituições e nos procedimentos guarde relação com a concepção hegemônica de democracia enquanto nada mais que instituições e procedimentos, e particularmente instituições e procedimentos que devem se reproduzir globalmente de forma acrítica. (...)

A preocupação a respeito dos perigos e equívocos imanentes a uma noção de democracia anacrônica e descontextualizada não é nova. Hobsbawm (2017), em 1963, escreveu:

Está claro, portanto, que qualquer tentativa de analisar a política da América Latina em termos europeus apenas cria confusão. Essa confusão torna-se ainda pior quando julgamos os países não somente em nossos termos, mas conforme nossas preferências; por exemplo, se têm eleições livres ou são contra ou a favor dos Estados Unidos. Para entender os países situados entre o Rio Grande e o Cabo Horn, não devemos olhá-los sob nossa luz, mas sob a deles. 
Estática e fascismo: sobre a formação dos golpes na América Latina

Revista Ensaios, vol. 13, jul-dez de 2018. ISSN 2175-0564.

Estas características, enumeradas no parágrafo anterior ao último, apontam para o caminho de uma necessária abordagem, a saber, a da estética. Mais precisamente, a da relação íntima entre estética e política, uma relação que se expressa na prática do real como uma necessidade mútua entre passado e presente, ou seja, entre concepção histórica (consequentemente, construção presente da narrativa histórica) e ação política. Pode-se dizer que o papel dos veículos de comunicação de massas é o mais fundamental. Depois das fracassadas tentativas de golpear a soberania popular no terceiro mundo se utilizando dos velhos métodos, o capital financeiro ${ }^{2}$ finalmente sentou e realizou sua autocrítica. Não podia, a curto prazo, sustentar-se em suas movimentações reacionárias sem que expusesse as contradições mais fundamentais ao Sul global ${ }^{3}$. Era necessário, desta forma, que estas contradições aparentassem ter natureza oposta à sua real natureza.

O fascismo ${ }^{4}$ deveria se parecer com o comunismo; a manutenção da ordem deveria se parecer com a revolução; finalmente, os golpes de Estado deveriam se parecer com o

${ }^{2}$ A respeito do capital financeiro, Hilferding (1985) escreve: "Uma porção cada vez maior do capital da indústria não pertence aos industriais que o aplicam. Dispõem do capital somente mediante o banco, que perante eles representa o proprietário. Por outro lado, o banco deve imobilizar uma parte cada vez maior de seus capitais. Torna-se, assim, em proporções cada vez maiores, um capitalista industrial. Chamo de capital financeiro o capital bancário, portanto o capital em forma de dinheiro que, desse modo, é na realidade transformado em capital industrial. Mantém sempre a forma de dinheiro ante os proprietários, é aplicado por eles em forma de capital monetário - de capital rendoso [portador de juros] - e sempre pode ser retirado por eles em forma de dinheiro." Em resumo, o capital financeiro é a fusão do capital bancário com o capital industrial; no longo prazo, este processo deu origem aos grandes monopólios dos grupos de investimento e a uma drástica queda no aspecto produtivo do capitalismo, que passou a ter sustento na especulação financeira. ${ }^{3}$ Bruckmann (2011): "El sistema mundial basadoenladivisión internacional deltrabajo entre las zonas industriales y manufactureras y los países productores de materias primas, minerales estratégicos y productos agrícolas, consolidóel poder hegemónico de los países centrales y sudominioenrelación a las zonas periféricas o dependientes y losespacios económicos que ocuparon una posición de semi-periferia." O Sul global, partindo desta concepção de divisão internacional do trabalho, é o conjunto de países, antes chamados de "terceiro mundo", cujo papel na economia global é o fornecimento de matérias primas, que são manufaturadas nos países industrializados do Norte global.

${ }^{4}$ A respeito do conceito de fascismo, é preciso notar que: a) as tendências neofascistas se diferenciam em alguns aspectos dos fascismos historicamente surgidos na primeira metade do século XX, apesar de também se aproximarem em vários aspectos, tendo em vista que nem as condições que pariram os primeiros fascismos são idênticas às atuais, embora seja possível encontrar semelhanças - principalmente no contexto de crise do capital, pode-se traçar paralelos entre 1929 e 2008 - nem as relações de produção e, portanto, as forças produtivas e a luta de classes cessaram o movimento dialético e permanecem iguais às da primeira metade do século $\mathrm{XX}$, b) embora seja tentadora a possibilidade de englobar indefinidamente diversos regimes e práticas dentro do conceito, é preciso se policiar contra isto, afim de prevenir a banalização e o esvaziamento do termo, para que este possa ser compreendido de uma maneira mais precisa e, finalmente, c) o pressuposto aqui apresentado sobre o termo parte da tradição marxista, cuja base pode ser encontrada na análise materialista e dialética de Marx a respeito do bonapartismo, com desdobramentos em pensadores posteriores da mesma tradição, como Thalheimer, Stalin, Adorno e Horkheimer; como coloca Thalheimer 
Estática e fascismo: sobre a formação dos golpes na América Latina

Revista Ensaios, vol. 13, jul-dez de 2018. ISSN 2175-0564.

mais radical exercício de constitucionalidade a que podem chegar os cidadãos. $\mathrm{O}$ estado de exceção se tornou mais excepcional ainda. Na Argentina, o governo do conservadorneoliberal Macri, alinhado aos interesses norte-americanos, implementou recentemente uma nova forma de coleta oficial de lixo que impede tanto que catadores coletem material reciclável e troquem por dinheiro, quanto que moradores de rua revirem as lixeiras para procurar restos de comida; toda a sorte de alimentos básicos, lá, está sendo racionada. Porém, a "ajuda humanitária” das grandes potências só tem olhos para a Venezuela.

Como pode ter vencido na América Latina este discurso? A mesma América Latina que na última década experimentou uma continental guinada à esquerda organizada pelos movimentos populares? Este trabalho pretende responder a estas perguntas a partir de uma investigação rigorosa, partida dos estudos de Walter Benjamin sobre reprodutibilidade técnica e sobre a história e dividida em quatro partes: a primeira, abrangendo aspectos teóricos da relação entre estética e política, e traçando diretrizes para compreender o que Walter Benjamin entendia por estética fascista; a segunda, analisando por um viés benjaminiano - a saber, sob a ótica da estética em Benjamin - a conjuntura da América Latina no período da "Onda Rosa" e as tentativas de golpe de Estado que respondem a este período, bem como o triunfo de governos e movimentos neofascistas em diversos países é dada atenção especial à tentativa de golpe contra o governo Chávez na Venezuela, em 2002; a terceira olha para o caso do Brasil, traçando relações diretas entre o papel da mídia na construção do escândalo do "mensalão" e o surgimento do fenômeno antipetista, que desemboca no golpe de Estado em 2016 e na vitória eleitoral do governo Bolsonaro; a quarta e última parte faz uma espécie de balanço breve dos casos estudados e encaixa-os numa síntese com as considerações teóricas da primeira parte, elaborando considerações práticas. A extensão aparentemente exagerada de algumas das notas de rodapé se explica

(2010): “O bonapartismo é, portanto, uma forma do poder do Estado burguês numa situação de defesa, de fortificação, de refortalecimento contra a revolução proletária. É uma forma da ditadura aberta do capital. Sua outra forma bastante semelhante é a do Estado fascista. O denominador comum é a ditadura aberta do capital. Sua forma de manifestação é a autonomização do poder Executivo, o aniquilamento do domínio político da burguesia, e a submissão política de todas as outras classes sociais ao poder Executivo. Seu conteúdo social, ou de classe, porém, é a dominação da burguesia e dos proprietários privados em geral, sobre a classe operária e todas as outras camadas exploradas pelo capitalismo." A definição de Stalin, sintetizada em uma entrevista ao jornalista inglês H.G. Wells em 1934, de viés mais geral e filosófico, é também importante: “O fascismo é uma força reacionária que tenta preservar, por meio da violência, o velho mundo." (Esta última encontra-se disponível em: https://www.marxists.org/portugues/stalin/1934/07/23.htm) 
Estática e fascismo: sobre a formação dos golpes na América Latina

Revista Ensaios, vol. 13, jul-dez de 2018. ISSN 2175-0564.

por dois motivos: o primeiro é a opção por manter, no texto propriamente dito, uma linha de raciocínio teórica que não seja interrompida por discussões já fundamentadas a respeito de alguns conceitos (como estética e fascismo); o segundo é a necessidade de explicar detalhadamente algumas dessas terminologias, para que elas não caiam em uma dimensão genérica desprovida de materialidade.

\section{Considerações teóricas sobre fascismo, estética e política}

Há, presentes nos estudos de Walter Benjamin (1985, 2005), pelo menos duas propriedades fundamentais no que diz respeito à estética ${ }^{5}$ fascista. Estas duas propriedades características dizem respeito à própria forma da obra de arte e como ela se modificou, e também como modificou seu modo de funcionamento e sua maneira de se posicionar no tecido social. São elas: primariamente, a estetização da política, isto é, a transferência da atividade e da operação da política do campo da realidade para o campo majoritariamente simbólico das representações e, em segundo lugar, as tecnologias de reprodução que possibilitaram que as obras se tornassem objetos de alcance e influência massivos.

A razão pela qual, no presente estudo, estas duas propriedades se encontram enumeradas em papel de importância se dá, principalmente, porque, apesar de terem importância ontologicamente inversa no que diz respeito ao sentido genealógico desta específica forma de estética ${ }^{6}$, esta ordem de importância é inteiramente diferente da ordem que define conceitualmente a própria citada estética como fascista. Isto acontece porque

\footnotetext{
5 Sobre o conceito de estética, o Dicionário Básico de Filosofia, de Danilo Marcondes e Hilton Japiassú (1996) diz, entre outras coisas: “1. (...) Para ele [Kant], a estética transcendental é a ciência de todos os princípios da sensibilidade a priori. Se a estética deve ser uma ciência, não pode ser a ciência do belo, apenas uma crítica do gosto. Ela é uma teoria dos princípios a priori da sensibilidade, teoria esta que se insere no conjunto da teoria do conhecimento da filosofia transcendental. (...) 3. Hegel afasta completamente do debate o problema da imitação da natureza, que não é, em si, nem bela nem feia. A arte não é outra coisa, diz Hegel, senão o mais subjetivo desenvolvimento do espírito a partir do real; e suas formas históricas representam, cada uma a seu modo, momentos desse desenvolvimento. (...)" Tanto a aproximação kantiana quanto a hegeliana são importantes para compreender o que Walter Benjamin pretende com o estudo da estética; a primeira é importante para compreender a resposta dialética de Benjamin a ela, e a segunda para compreender a origem da posição de Benjamin - que, por ser da tradição marxista, incorpora elementos da filosofia de Hegel, porém com o idealismo enxugado.

${ }^{6}$ No que diz respeito à condição de existência desta forma de estética, Benjamin (1985) deixa claro que as técnicas de reprodução da obra de arte têm uma importância anterior ao processo de estetização da política, pois foram elas que trouxeram, antes, a possibilidade prática deste processo. Já não acontece o mesmo se for deslocado o centro da discussão da condição de existência desta forma de estética para a sua conceituação $e$ funcionamento.
} 
Estática e fascismo: sobre a formação dos golpes na América Latina

Revista Ensaios, vol. 13, jul-dez de 2018. ISSN 2175-0564.

por mais que a estética fascista se valha das técnicas de reprodução que permitem o alcance da obra de arte às massas, estas técnicas são características apenas da própria forma da obra de arte de que se vale a estética fascista, e não ao conjunto de pressupostos e sistematizações filosóficas, políticas e sociais de que é feita a constituição da estética.

No ensaio "A obra de arte na era de sua reprodutibilidade técnica", logo ao final, Benjamin descreve o processo de estetização da política como o inverso da resposta dialética que a estética antifascista tem de oferecer: a politização da arte. Parece, deste modo, que os dois processos opõem-se num espectro, e portanto a diminuição da intensidade de um ocorre quando aumenta a intensidade de outro ${ }^{7}$.

Há uma relação bastante sutil e muito pouco explícita, ao que parece, entre o que o autor desenvolve no ensaio já citado e o problema central de outro texto seu, bastante conhecido, as teses "Sobre o conceito de história", redigidas no desespero da tentativa de Benjamin de escapar das mãos da Gestapo e ainda assim detentoras de imensa profundidade e inegável precisão teórica, prática e metodológica. O problema é o da historiografia burguesa e o cortejo dos vencedores ${ }^{8}$. Para o filósofo, é imprescindível que sejam questionados os próprios métodos da historiografia se existem pretensões de construir uma nova historiografia, revolucionária e com impacto político na contemporaneidade. Benjamin trata da luta de classes em uma dimensão histórica tão radical que é perceptível, pelo menos neste aspecto específico (o histórico), o seu distanciamento, no sentido de avanço, dos autores marxistas tradicionais e até do próprio Marx. O reconhecimento da dinâmica do materialismo histórico marxista, o qual aponta que a história das sociedades humanas tem sido a história da luta de classes (Marx, 1998), fez com que o autor radicalizasse mais ainda este pressuposto: além de a história ser a história da luta de classes, ela é contada tradicionalmente pelos que, até hoje, venceram esta luta, isto é, os opressores. Desta forma, é fundamentalmente necessário que a

\footnotetext{
${ }^{7}$ Walter Benjamin, assim como todos os outros autores da tradição frankfurtiana, era marxista por formação e convicção; afere-se, portanto, que o mais auto grau de antifascismo estético só pode ser encontrado na estética comunista, a quem ele sugere a resposta de politização da arte no final do ensaio mencionado.

${ }^{8}$ Tese VII das teses "Sobre o conceito de história", referenciada na bibliografia dentro de BENJAMIN, W. In: LÖWY, M.
} 
Estática e fascismo: sobre a formação dos golpes na América Latina

Revista Ensaios, vol. 13, jul-dez de 2018. ISSN 2175-0564.

pretensão revolucionária dos oprimidos passe, sem desvios, pela via da construção de uma historiografia que conte a história dos vencidos.

Benjamin (2005) articula mutuamente as duas coisas: a importância de "capturar" o passado, para que, então, ele possa servir de combustível e fazer rodar o presente. É somente através do resgate histórico dos oprimidos do passado, isto a que ele chama de "Tradição dos Oprimidos", que se torna possível à geração presente de oprimidos a organização revolucionária contra os opressores.

Uma breve, porém preocupada e curiosa, análise tanto das teses como do ensaio faz com que uma sutileza, talvez disfarçada, seja percebida: há uma relação bastante íntima entre a historiografia burguesa e a estetização da política, característica que é chave da estética fascista. Há uma relação de dependência entre a manutenção do cortejo aos vencedores na historiografia burguesa e a incessante vitória contínua destes vencedores ${ }^{9}$, de forma que se tornaria insustentável vencer se esta relação fosse rompida, e também no desenvolvimento e sustento do fascismo há uma relação de dependência entre a transferência contínua da política para o campo simbólico e narrativo e o seu contínuo suporte por parte das massas. Parece, finalmente, que além dessas relações inerentes às duas regiões ${ }^{10}$, há ainda uma inter-relação entre as duas regiões, elas mesmas: o avanço do fascismo é uma radicalização da vitória dos que saem continuamente vitoriosos na luta de classes, e ao mesmo tempo esta vitória só pode se exacerbar graças à radicalização cada vez maior do cortejo aos vencedores na historiografia burguesa, e esta última radicalização, por sua vez, só foi possível graças ao avanço no desenvolvimento das técnicas de reprodução que possibilitaram, por último, estetização da política. Em resumo, parece que, ao longo do tempo, o cortejo aos vencedores encontrou na estética fascista um forte aliado que fez crescer sua estrutura.

É neste sentido que parece, em última instância, válida a afirmação de que, se o fascismo ele mesmo não venceu a Segunda Grande Guerra contra os aliados, pelo menos sua forma de organização estética e, portanto, política, venceu. Ou é incorreto afirmar

\footnotetext{
${ }^{9} \mathrm{O}$ maior sinal disto é o grau de importância que Benjamin confere ao processo de construção de uma historiografia contrária a esta para a possibilidade de organização revolucionária.

${ }^{10} \mathrm{O}$ fascismo e a vitória dos vencedores na luta de classes.
} 
Estática e fascismo: sobre a formação dos golpes na América Latina

Revista Ensaios, vol. 13, jul-dez de 2018. ISSN 2175-0564.

também que se valeram os historiógrafos burgueses, assim como os meios de comunicação de massas que serviram para difundir o discurso destes historiógrafos, da metodologia estética do fascismo? Não constitui uma evidência clara disto a constante e cada vez maior transferência da política para o campo simbólico à medida que o capitalismo se desenvolve e se torna cada vez mais autoritário nos dias de hoje?

Se antes, o fascismo declarado, à moda antiga, era a expressão mais autoritária do capitalismo em tempos de crise, hoje, já não funciona desta forma, com exceção de algumas raras experiências onde aquele mesmo fascismo parece retornar ${ }^{11}$. O fascismo, hoje, é uma estranha e improvável junção de duas coisas que parecem, e são, contraditórias: liberalismo e autoritarismo. À medida que se desenvolve, o capitalismo precisa ser sustentado por alguma forma cada vez mais eficiente de camuflar suas contradições, porque estas contradições se desenvolvem junto com ele. Quando o fascismo surgiu e avançou como expressão máxima destas contradições, na primeira metade do século XX, elas ficaram demasiadamente evidentes, expostas à luz do dia, como já vinham se mostrando cada vez mais com o desenvolver das relações de produção capitalistas. Porém, de forma embrionária, ele parece ter apresentado a solução para este problema: sua máquina de propaganda. E o capitalismo, outra vez, renovou-se com o desenvolvimento

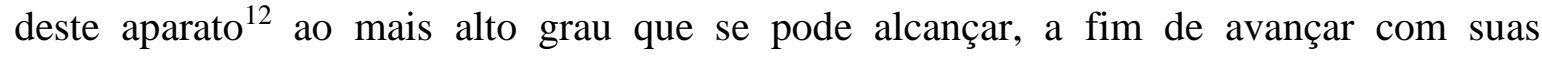
contradições sem que fossem percebidas. 11 Pode-se sugerir também que isto acontece onde não é possível sofrer explicitamente os impactos do
desenvolvimento do estágio atual do capitalismo de maneira clara.
12 O aparato deve ser entendido precisamente como o conjunto de elementos que se organizam de maneira a
sustentar a narrativa de interesse do capital: os meios de comunicação de massa como jornal impresso,
telejornal, revista, rádio, a indústria cultural (Adorno/Horkheimer, 1985) e todas as formas de produção
"artística” que ela engloba - no caso de Benjamin (1985), isto significa olhar essas formas também pela lente
da reprodutibilidade técnica. Quanto ao desenvolvimento deste aparato, deve-se entende-lo tanto pelo
desenvolvimento de tecnologias que facilitem o exercício da reprodutibilidade técnica (destacam-se, por
exemplo, os avanços científicos que implicaram em popularização mercadológica e possibilitaram a difusão
da televisão e do rádio como objeto presente na esmagadora maioria das casas) e, portanto, da aproximação
da obra reproduzida com as massas, bem como pelo desenvolvimento de tecnologias que atualizem a
eficiência no funcionamento da aparelhagem necessária para o processo (como, por exemplo, o surgimento
da TV a cores, que significou uma maior precisão na captura da realidade), desenvolvimento este que implica
sempre na atualização do próprio processo. Exemplos desse conjunto de explicações são os dados do IBGE,
disponíveis em https://ww2.ibge.gov.br/censo/divulgacao.shtm e https://censo2010.ibge.gov.br/, que indicam
respectivamente que, em $2000,87,9 \%$ das casas no Brasil possuía pelo menos um aparelho de rádio e $87,2 \%$
possuía pelo menos um aparelho de TV e, em 2010 , o número de casas que possuem pelo menos um aparelho 
Estática e fascismo: sobre a formação dos golpes na América Latina

Revista Ensaios, vol. 13, jul-dez de 2018. ISSN 2175-0564.

A nova expressão fascista, isto é, esta fusão de liberalismo e autoritarismo, sustentase por enquanto pelas atualizações deste aparato. Por isto mesmo o autoritarismo inerente ao capitalismo, como se observa hoje, não parece autoritarismo. Eis o grande trunfo dos neofascistas.

\section{Estética e avanço do neofascismo na América Latina}

À medida que se desenvolve, uma das principais contradições que o capitalismo mostra é a aquela entre sua própria lógica de funcionamento e qualquer forma de democracia $^{13}$; neste sentido, parece claro que, agora, ele se encontra em um momento de mudança relativa ao desenvolvimento desta contradição. As guinadas à direita autoritária, principalmente no Sul global, em contraposição à “Onda Rosa” demonstram que é cada vez menos necessária a democracia ao capitalismo. Porém, paradoxalmente, a democracia é também cada vez mais alvo de reivindicações das classes trabalhadoras, que sentem mais radicalmente as contradições do avanço do capitalismo.

De que forma é possível, então, que justamente agora é que se avance também o neofascismo, que é o mais perfeito avesso da forma de democracia a que tende o proletariado? A resposta para isto é que a estetização da política se tornou proporcionalmente mais radical à reivindicação das massas por participação política.

Em 1998, Hugo Chávez foi eleito presidente da Venezuela com cerca de $56 \%$ dos votos (contra $40 \%$ do opositor de direita, Henrique Salas Römer) e uma plataforma política

de TV passa para 95,1\% e o de casas que possuem um aparelho de rádio cai para $81,4 \%$; isto demonstra um desenvolvimento no aparato, principalmente quando se contrasta as eficácias do rádio e da TV no sentido de exercer a reprodutibilidade técnica: a TV, notavelmente, serve mais a este propósito e, portanto, ditou uma certa obsolescência do rádio.

${ }^{13}$ Neste caso, em específico, fala-se da democracia liberal, forma de governo vigente como expressão da sociedade burguesa; esta forma, se vista sob a lente de rigor marxista, não constitui uma democracia concreta, e a forma de democracia em que constitui a ditadura do proletariado, obviamente, é a forma que se coloca como mais radical oposição diametral à lógica do capital, por isto mesmo é a forma defendida pelos marxistas e foi/é a forma das experiências socialistas de orientação comunista. 
Estática e fascismo: sobre a formação dos golpes na América Latina

Revista Ensaios, vol. 13, jul-dez de 2018. ISSN 2175-0564.

de esquerda, progressista ${ }^{14}$, que se fomentava na organização das massas de trabalhadores e da população mais pobre nos entornos de pautas que traduziam suas reivindicações. Foi um feito e tanto, visto que Chávez já havia sido preso anos antes por tentar tomar o poder à força, em conjunto com uma pequena parcela de militares de esquerda. Em pouco tempo, Chávez foi liberto e começou uma movimentação política que organizou o proletariado e o campesinato do país e o elegeu presidente. Este evento é importante, pois iniciou dois ciclos: primeiro, o do avanço de vários outros governos de esquerda na América Latina que buscavam independência do neocolonialismo para fazer frente ao mercado global dominado pela economia estadunidense, emergir da condição de subdesenvolvimento e, consequentemente, melhorar as condições de vida das classes trabalhadoras e da população pobre; depois, o do avanço do que alguns estudiosos, como Pereira da Silva (2018), chamam de neogolpismo, que foi a resposta do imperialismo das grandes potências (principalmente os Estados Unidos) a estes movimentos de esquerda latino-americanos, na tentativa de esmagá-los e manter a hegemonia econômica, cultural e política na região. Monica Bruckmann (2011), cientista política da Universidade Federal do Rio de Janeiro, analisa a estratégia norte-americana de dominação regional visando o controle sobre os recursos naturais:

\footnotetext{
${ }^{14}$ Não no sentido benjaminiano.
}

La gestión social, económica y científica de los recursos naturalesasumeun rol fundamental enelprocesocivilizatorio de lahumanidad y enlareestructuracióndel capitalismo mundial, que desarrolla diferentes estrategias desde el centro, desde las potencias emergentes y desde los países productores de materias primas. (...)

La articulación de losvarios documentos que expresanelpensamiento y losintereses estratégicos de Estados Unidos muestran que, para este país, elacceso y eldominio de los recursos naturales a nivel global constituyen una cuestión de interés y de seguridad nacional, garantizados por underecho unilateral para usar lafuerza militar ensuconsecución. Esta política forma parte de una estrategia multidimensional de dominación, que integra "todas lasherramientasdel poder estadounidense" para conseguir elfortalecimiento de lacapacidad nacional como un todo (...). 
Estática e fascismo: sobre a formação dos golpes na América Latina

Revista Ensaios, vol. 13, jul-dez de 2018. ISSN 2175-0564.

Assim que tomou posse, em 1999, Hugo Chávez começou a implementar reformas estruturais nas lógicas política e econômica da Venezuela. Como descreve Lander (2005):

Durante os primeiros dois anos de governo, a prioridade esteve na mudança institucional, na passagem da chamada Quarta República à Quinta República. Em janeiro de 1999, no mesmo dia em que tomou posse como Presidente da República, Chávez anunciou um referendo para consultar a população sobre a convocação de uma Assembléia Constituinte. Obteve um apoio majoritário em tal referendo, e conseguiu igualmente uma ampla maioria na Assembléia Constituinte, o que, unido ao peso preponderante de sua liderança pessoal, o coloca em condições de influir fortemente na orientação da nova Constituição, mesmo em temas polêmicos para seus próprios seguidores, como a mudança do nome do país para República Bolivariana da Venezuela.

Todo este processo, que continuou e continua por muitos anos e inclui nacionalização de empresas que exploram recursos naturais do país, distribuição de renda, reformas midiáticas e uma vigente reforma constitucional eleita popularmente, constituem o que Chávez chamou de Revolução Bolivariana ${ }^{15}$. No curso destas transformações na Venezuela, seguiram-se muitos movimentos de esquerda no resto da América Latina: o Brasil elegeu, em 2002, Luís Inácio Lula da Silva, operário e candidato do Partido dos Trabalhadores, em uma aliança dos movimentos operários urbanos com os movimentos do campesinato pela reforma agrária; a Argentina elegeu em 2003 Néstor Kirchner, candidato do operariado de tendência peronista ${ }^{16}$ e social-democrata; Tabaré Vázquez, do Frente Amplio, partido que engloba vários partidos e movimentos da esquerda uruguaia

\footnotetext{
${ }^{15}$ Símon Bolívar foi um independentista e um dos mais importantes líderes da história da Venezuela e da América Latina, tendo lutado na guerra de descolonização contra o Império Espanhol.

${ }^{16}$ Chama-se assim os adeptos da abordagem de pensamento do General Juan Domingo Perón, líder nacionalista argentino e fundador do maior partido da Argentina, o Partido Judicialista (Partido Peronista, por vezes). Perón foi responsável por várias estatizações de empresas antes dominadas pelo setor privado. Junto com outros líderes políticos e militares latino-americanos, integrou a onda de movimentos que ficaram conhecidos como "populistas". Sobre o conceito de populismo, Hobsbawm (2017) diz: "Por outro lado, o observador sem preconceitos logo descobrirá que há uma forma latino-americana característica de movimento político que não a periódica ditadura militar. É o que se pode chamar de 'populismo': um movimento de massas dos pobres contra os ricos, mas apoiado igualmente por militares e intelectuais, ao mesmo tempo - se os termos não forem demasiado enganosos - nacionalista e socialmente revolucionário, às vezes mal ou quase nada organizado em geral construído ou moldado em torno de algum demagogo ou figura de líder. (...) O peronismo na Argentina, o getulismo no Brasil, o Movimento Nacionalista Revolucionário na Bolívia, a Apra no Peru, a Ação Democrática na Venezuela, o movimento do falecido EliécerGaitán na Colômbia são ou foram fenômenos desse tipo. (...) O auge desses movimentos ocorreu entre o final da década de 1930 e meados dos anos 1950, embora alguns, como a Para no Peru, tenham uma história bem mais longa."
} 
Estática e fascismo: sobre a formação dos golpes na América Latina

Revista Ensaios, vol. 13, jul-dez de 2018. ISSN 2175-0564.

(incluindo o antigo revolucionário FLN-Tupamaros, do ex-guerrilheiro e ex-presidente José Mujica) se elegeu em 2004 no Uruguai; na Bolívia, Evo Morales, representante do campesinato indígena e dos trabalhadores urbanos com tendências social-democratas e nacionalistas, venceu em 2005; no Equador, o social-democrata Rafael Correa vence em 2006 com uma coligação de esquerda nacionalista; finalmente, em 2008, venceu no Paraguai Fernando Lugo, líder político de esquerda e bispo ligado às movimentações da Teologia da Libertação ${ }^{17}$.

Evidentemente, este processo não agradou os interesses do capital norte-americano, que foi perdendo cada vez mais influência no país e, com a influência, a capacidade de controlar a exploração de recursos naturais (principalmente petróleo).A respeito das acirradas relações entre o governo Bush e o governo Chávez, depois do início das reformas no setor petrolífero venezuelano, Lander e Lopez Maya (2002) comentam:

Sin embargo, para nadie es un secreto que enelactualgobierno de EE.UU. losinteresesdel sector petroleroestánmuybien representados, y no parece que vaya a ser este gobiernoquien impulse políticas dirigidas a abatirlosprecios. No es aquí donde debanesperarsemayorestensiones entre ambos países, aunque es innegable que larelacióndirecta de los EE.UU. conla gerencia de $\mathrm{P}$ DVSA resultaría más fluida que confuncionarios de este gobierno. Los primerossiemprehan privilegiado losintereses de la empresa sobre los de lanación. No es casual que el principal promotor de lallamada Apertura Petrolera desde lapresidencia de PDVSA, el Ing. LuisGiusti, seahoy uno de losasesorespetrolerosdelgobierno de Bush.

Pero hayotras áreas delnegociopetrolero donde losintereses de los EE.UU. son más uniformes y distintos a los de Venezuela. Ha sido uma

posicióntajantedelactualgobiernovenezolanosucompromisoconla

OPEP. Sinduda, lamayorrelevanciaactual de esta organizaciónenelescenario mundial es parte de loshaberes de Chávez y su política petrolera. Conesto no solamente se ha logrado larecuperación de losprecios de loshidrocarburosenel mercado mundial, sino que además se ha fortalecido a laorganización y a los países que laintegran. El fortalecimiento político de la OPEP y sus países miembros no puede sino causar aprehensión, cuando no

\footnotetext{
${ }^{17}$ Movimento de representantes e teólogos católicos de esquerda que reinterpreta a história e os ensinamentos de Jesus Cristo através da perspectiva da luta de classes, advogando que Cristo era um advogado da justiça social em defesa dos oprimidos. No Brasil, o maior expoente deste movimento é Leonardo Boff, teólogo católico e militante perseguido pela Ditadura Militar e pelo Vaticano por, respectivamente, "ameaça à segurança nacional" e "heresia".
} 
Estática e fascismo: sobre a formação dos golpes na América Latina

Revista Ensaios, vol. 13, jul-dez de 2018. ISSN 2175-0564.

abiertomalestar, enelgobierno de los EE.UU. No debeolvidarse que forman parte de laorganización países que sontenidos por esegobierno como sus “enemigos”: Irak, Libia, Irán.

Antes de outros governos de esquerda começarem a se eleger na América Latina, ensaiou-se em 2002, na Venezuela, o que se tornaria, embora posteriormente de forma muito mais sofisticada e menos falha, a prática constante do imperialismo norte-americano no resto do continente: um golpe de Estado contra Hugo Chávez, orquestrado, principalmente, pela oposição mais alinhada ao neoliberalismo e financiada pelos interesses norte-americanos, que convergem com os do capitalismoglobal, em conjunto com a imprensa local, que movimentou as parcelas mais significativas da classe média e classe média-alta. Esta forma ainda recém-nascida de golpismo ainda não se encaixa dentro da categoria de neogolpismo, descrita por Pereira da Silva (2018); antes, é uma

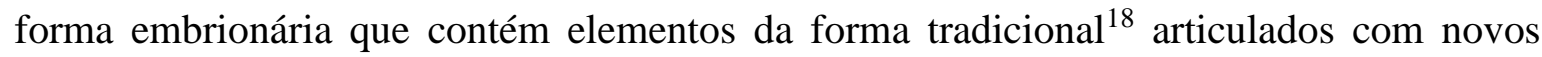
recursos, dentre eles, principalmente a difusão massiva de uma narrativa específica dos acontecimentos.

O golpe de Estado colapsou em dois dias, e Chávez voltou ao poder com enorme mobilização popular e militar de oficiais e frações majoritárias do exército venezuelano que se mantiveram fiéis à constituição. Esta movimentação caótica e, a princípio, bastante desconexa foi documentada no filme "A revolução não será televisionada", pelas cineastas irlandesas Kim Bartley e Donnacha O’Briain, que estavam, na ocasião, visitando a Venezuela para gravar um documentário sobre o governo chavista. Não se tinha registro, até então, de nenhum outro ocorrido parecido com este na América Latina, no que diz respeito à participação central dos meios de comunicação de massas. As principais emissoras de TV privadas da Venezuela, como a RCTV e a Venevision, todas

${ }^{18}$ Sobre a forma tradicional do processo conhecido universalmente como "golpe de Estado", Hobsbawm (1982) delimita: "Desde Maquiavel, observadores inteligentes têm explorado um dos recursos estilísticos mais eficazes da não-ficção: o contraste entre as versões oficiais da vida política e a realidade. Trata-se de um recurso eficiente por três razões: porque a realidade política está notoriamente em discrepância com o artifício moral, constitucional ou legalista que envolve as ações políticas e porque, surpreendentemente, o público pode ser ainda facilmente escandalizado por ele. (...) Um golpe é um jogo com três jogadores (omitimos a potência ou empresa estrangeira dominante que pode ter os trunfos ou um efetivo poder de veto): as forças armadas, que podem levá-lo a cabo; os políticos e os burocratas, cuja disposição em aceitá-lo o faz viável; e as forças políticas, oficiais ou não, que podem detê-lo ou derrota-lo totalmente. Porque o êxito de um golpe depende essencialmente da passividade do aparato estatal existente e do povo." 
Estática e fascismo: sobre a formação dos golpes na América Latina

Revista Ensaios, vol. 13, jul-dez de 2018. ISSN 2175-0564.

declaradamente alinhadas à oposição, cobriram exaustivamente as manifestações convocadas pelas suas principais lideranças, como Pedro Carmona, e por vezes também elas próprias fizeram convocações.

Um detalhe ocorrido no meio deste papel desempenhado interessa particularmente a este estudo. Não era novidade alguma que nem a elite financeira da Venezuela, ligada ao setor petrolífero, nem os veículos de comunicaçãoeram simpáticos ao governo de Hugo Chávez, e movimentações da oposição, como passeatas, eram constantes. O governo e os partidos de esquerda da base governamental também organizavam passeatas, que reuniam uma quantidade muito grande de populares favoráveis ao governo. Numa determinada ocasião, a oposição marcou uma marcha para o mesmo dia em que o governo havia marcado a sua. De repente, uma ordem vinda não se sabe de que fonte, direcionou a manifestação da oposição para o mesmo local onde estava acontecendo a manifestação dos partidários de Chávez, o Palácio Miraflores. No mesmo instante, coordenadamente, todos os veículos de comunicação já tinham suas câmeras posicionadas, quando, de repente, começara-se a ouvir tiros, vindos também não se sabe de onde. Civis começaram a cair, mortos, com tiros de alta precisão na cabeça. Logo se percebeu que era uma ação implementada por francoatiradores de elite. Mais e mais civis eram assassinados, e todos continuavam sem saber de onde, exatamente, vinham os tiros. Lopez Maya (2002) narra com precisão:

El 11 de abril, una nutrida marcha se inicióhacialas 10 de lamañana e hizosu recorrido anunciado. Pero al mediodía, al llegar al edificio de PdvsaenChuao, losconvocantes, Fedecámaras, la CTV y algunos dirigentes de lasotrasorganizacionessociales, animados por las dimensiones de la marcha decidieron arengar a lasmultitudes para que se dirigiesen al Palacio Presidencial de Miraflores para, como loseñaló Carlos Ortega, presidente de la CTV, "sacar a Chávez". La marcha, elmensaje y laconvocatoria a Mirafloresfueron profusamente informadas, convocadas y cubiertas por loscanales privados de televisión. [...]

[...] Pronunciamientos militares enlos últimos meses corroboran que enloscuarteleshayinquietud y rebelión. Los simpatizantes del Presidente estánresentidos. Se agolpanalrededor de Miraflorescon gritos de confrontación: "No pasarán", repiten.

[...] Al entrar la marcha oposicionista al centro de Caracas (aproximándose al palacio presidencial), comienzanlosdisturbios. Hacialas 2.00 pmlasmultitudesprochavistasestán tirando piedras, 
Estática e fascismo: sobre a formação dos golpes na América Latina

Revista Ensaios, vol. 13, jul-dez de 2018. ISSN 2175-0564.

paloshaciael hotel Edén, que queda al lado delPalacio de Miraflores, donde aparentemente francotiradores apostados enlaterrazaestánatacándolos. [...] Aparecen personas armadas de lado y lado de laconfrontacióncallejera, laviolencia se desata y al final de la tarde el número de muertosalcanzalas 19 víctimas, pro y anti-chavistas.

Naquela noite e nos próximos dias, os jornais começaram a exibir uma gravação mostrando o seguinte: duas manifestações acontecendo ao mesmo tempo, no mesmo lugar, quando, de repente, chavistas começam a atirar, posicionados em cima de um viaduto, para fora dele, e, logo em seguida, aparecem as imagens de manifestantes sendo abatidos na rua. A responsabilidade pelo massacre foi atribuída a Hugo Chávez e aos partidos de esquerda, acusados de terrorismo pela imprensa nacional e internacional ${ }^{19}$, e começa uma ampla e muito mais intensa movimentação da classe média e da classe média-alta pela derrubada de Chávez.

O que não se mostrou nestes vídeos divulgados pela imprensa foi que, no momento em que os chavistas se encontravam em cima do viaduto atirando na direção contrária, a parte da rua embaixo do viaduto, onde as imagens sugeriram que os manifestantes da oposição estavam, estava vazia. Não deu-se atenção também ao fato de que todos os tiros, que abateram civis, acertaram precisamente na cabeça. Tudo isto foi ignorado. As notícias que as imprensas nacional e internacional repercutiram foram as de que Chávez e sua horda de comunistas autoritários haviam massacrado opositores do governo, e rapidamente surgiu a necessidade de remover Chávez da presidência da república para que "se restaurasse a democracia”.

Criou-se, finalmente, a imagem do inimigo. Toda a carga simbólica ${ }^{20}$ do conceito de "mal” foi atribuída a Chávez, e toda a carga simbólica do conceito de "bem” foi atribuída

19 Acerca desta participação há, além dos artigos citados de estudiosos do assunto, um relato redigido pelo jornalista francês Maurice Lemoine para o Le Monde Diplomatique. Disponível em https://mondediplo.com/2002/08/10venezuela.

${ }^{20}$ A respeito da criação desta carga simbólica, é importante ter em foco a noção de violência apresentada por SlavojZizek (2014), e que permeia os diversos ensaios sobre o fenômeno da violência. Para o autor, a violência precisa ser analisada para além do aspecto visível e explícito, de maneira a revelar uma violência mais silenciosa e simbólica que funda as condições em que surgem os seus aspectos concretos. O autor dá ênfase ao poder criativo desta forma de violência, que origina uma representação simbólica verdadeiramente violenta em contraposição à resposta violenta - e dialética - da realidade. Deste conjunto de observações 
Estática e fascismo: sobre a formação dos golpes na América Latina

Revista Ensaios, vol. 13, jul-dez de 2018. ISSN 2175-0564.

aos opositores, que agora clamavam por uma intervenção internacional para remover o presidente. Em questão de dias, uma pequena fração do exército cercou o Palário de Miraflores, residência presidencial, e sequestrou Hugo Chávez, que foi levado de helicóptero para La Orchila, ilha de administração militar próxima a Caracas onde funciona uma prisão do exército venezuelano. Todos os membros do governo presentes no momento fizeram questão de declarar aos cineastas e jornalistas dos veículos de esquerda que Chávez não havia renunciado ${ }^{21}$, e que, portanto, aquilo se tratava de um golpe de Estado. Momentos depois, a imprensa nacional começou a difundir a informação de que Chávez havia renunciado. Imediatamente, os veículos internacionais ecoaram a "notícia". Pedro Carmona, empresário e, na época, presidente da Federação Venezuelana das Câmaras de Comério, foi empossado como presidente da república. A Assembleia Nacional foi dissolvida, o Supremo Tribunal foi desautorizado e a constituição redigida após o referendo popularde 1999 foi revogada. Representantes do novo governo e líderes da oposição foram às entrevistas na imprensa e agradeceram publicamente aos veículos de comunicação.

Os partidos de esquerda e as frações constitucionalistas do exército, que eram maioria, imediatamente organizaram a mobilização nacional pela devolução do mandato e contra o golpe de Estado. Dias depois, o governo colapsou e os militares leais tomaram de volta o Palácio de Miraflores, que agora estava cercado de uma massa popular pedindo a volta do presidente, renderam os representantes do governo golpista e restabeleceram aos poucos a ordem constitucional com os membros do governo e, posteriormente, o resgate de Hugo Chávez e restauração de seu mandato.

A narrativa detalhada desta sequência de eventos se deu porque foi um episódio fundamental para compreender como se desenvolveu, através desta experiência, a metodologia de aplicação da estética fascista nos outros golpes da América Latina. Houve

parte a afirmação de que uma carga simbólica foi atribuída à figura de Chávez; criou-se nele, através deste processo, um símbolo de mal que reunia em si todos os medos fomentados pelo discurso, bem como se criou nas figuras de oposição, especialmente em Pedro Carmona, um símbolo de bem que funcionaria como antídoto a este mal. A violência simbólica está, desta forma, na contradição entre a realidade e o discurso. Esta noção de violência, em Zizek, está firmemente assentada na noção de Walter Benjamin (2011), presente no ensaio "Para uma crítica da violência".

${ }^{21}$ Cena presente no documentário anteriormente citado. 
Estática e fascismo: sobre a formação dos golpes na América Latina

Revista Ensaios, vol. 13, jul-dez de 2018. ISSN 2175-0564.

duas principais falhas no golpe de 2002 na Venezuela: a primeira e mais importante foi o fato de ele ter se parecido com um golpe, e a segunda foi que o alcance da simbologia política criada nos arredores da movimentação não foi suficiente em relação às massas, o que possibilitou que houvesse contrárias mobilizações gigantescas a nível nacional e também que as frações constitucionalistas do exército se mantivessem leais ao governo de Chávez. Estas falhas não viriam a se repetir na maioria das próximas investidas imperialistas em outros países latino-americanos.

Formava-se, agora, uma linha de desenvolvimento da estetização da política na metodologia neogolpista, que partia da questão: como fazer com que um golpe de Estado se pareça com o total oposto de um golpe de Estado? A resposta começa por perpassar o fato de que, na prática contemporânea, isto significa garantir a simbologia da democracia liberal, como bem aponta Pereira da Silva (2018), mesmo que ela própria seja violada. E foi isto que começou a ser desenvolvido nas próximas investidas.

Em 2005, no Brasil, houve uma tentativa de golpe de Estado contra o ex-presidente Lula. $^{22}$ A imprensa, mais uma vez, teve papel decisivo e, agora, mais sofisticado. O que abriu a movimentação dos veículos de comunicação naquele ano foi uma reportagem de autoria da revista $\mathrm{Veja}^{23}$, uma tradicional revista brasileira de tendência conservadora, apontando um suposto esquema de corrupção e compra de votos envolvendo líderes do governo Lula. A imprensa repercutiu exaustivamente o conteúdo da reportagem, como observa Maria Terezinha da Silva (2014), apelidando o esquema de corrupção de "mensalão", e a expressão foi repetida nos veículos internacionais de tendência conservadora. Imediatamente, líderes da oposição, destacando-se figuras-chave do Partido da Social Democracia Brasileira (PSDB), como o ex-presidente Fernando Henrique

\footnotetext{
22 Esta tese da tentativa de golpe é apoiada em estudos a respeito do que ficou conhecido no imaginário popular como "escândalo do mensalão". Um destes estudos, redigido por Maria Terezinha da Silva (2014), pesquisadora da Universidade Federal de Minas Gerais, analisa o impacto do episódio no cenário político brasileiro da época e atual a partir do percurso pelos seus campos simbólicos. Diz a autora: "O 'Mensalão' é, certamente, um divisor de águas no campo da política institucional do país. Polarizou visceralmente grupos político-partidários opostos, cidadãos e segmentos jornalísticos durante e após sua ocorrência. Modificou a forma como o PT e petistas eram antes simbolicamente representados. Reconfigurou o cenário dos afetos, das filiações e das identidades partidárias."

${ }^{23}$ A respeito desta cronologia, a própria revista apresenta os detalhes e um artigo, de 2015. Disponível em https://veja.abril.com.br/brasil/os-segredos-do-mensalao-dez-anos-depois/.
} 
Estática e fascismo: sobre a formação dos golpes na América Latina

Revista Ensaios, vol. 13, jul-dez de 2018. ISSN 2175-0564.

Cardoso, começaram a movimentar uma fração da classe média e da classe média alta, pedindo pela abertura de um processo de impeachment contra o então presidente Lula, acusado por eles de ser a autoridade maior do esquema. Sem sucesso, devido à popularidade de Lula na época, as marchas da oposição perderam força rapidamente, mas a base do governo, que incluía o Partido do Movimento Democrático Brasileiro (PMDB) no legislativo, manteve-se fiel e o golpe fracassou.

No entanto, desta vez, a estrutura da simbologia a que se submeteu o processo político já estava muito mais desenvolvida e firme, o que a impediu de ruir. A movimentação da imprensa que inicialmente tinha um papel golpista imediato, se tornou o embrião de uma forma de paranoia ${ }^{24}$ hoje conhecida como o fenômeno do "antipetismo" 25 . Uma marcante característica deste fenômeno é a peculiaridade com que ele se move no tecido da realidade: sua principal conquista não foi simplesmente deteriorar a imagem do Partido dos Trabalhadores e seus principais líderes, mas a imagem da própria ideia de esquerda no imaginário popular, como apontam Ribeiro, Carreirao e Borba (2016), e articular esta paranoia de maneira muito semelhante à do anticomunismo, típica da Guerra Fria, o que possibilitou a justificativa do avanço significativo dos setores mais reacionários da sociedade brasileira.

Quase todos os golpes e tentativas de golpe na América Latina seguiram esta linha midiática pautada na difusão, pelos meios de comunicação de massas, de realidades simbólicas e fabricadas da política, com exceção do golpe em Honduras, ocorrido em 2009, que foi, por definição, um golpe militar, mesmo que contivesse elementos característicos do neogolpismo, como aponta Pereira da Silva (2018). A popularidade do casal Kirchner na Argentina foi perdendo espaço para a narrativa de corrupção construída pela imprensa e, nas eleições presidenciais de 2015, Macri, o candidato de oposição alinhado à agenda econômica neoliberal, foi eleito presidente, encerrando o período de governo kirchnerista. O nome da coligação? Mudemos. Cristina Kirchner hoje (2019) lidera as pesquisas presidenciais, com a queda monumental da popularidade de Macri

\footnotetext{
${ }^{24}$ No modelo pelo qual se entende a paranoia anticomunista da Guerra Fria.

${ }^{25}$ A respeito do antipetismo, recomenda-se o artigo "Sentimentos partidários e antipetismo", de Ednaldo Ribeiro, Yan Carreirao e Julian Borba (2016).
} 
Estática e fascismo: sobre a formação dos golpes na América Latina

Revista Ensaios, vol. 13, jul-dez de 2018. ISSN 2175-0564.

devido ao desastroso resultado que suas políticas de privatização e ajuste fiscal obtiveram, engendrando uma das piores recessões econômicas da história da Argentina. Ela sofre, também, um processo de julgamento político com cobertura midiática aos moldes da que a imprensa brasileira deu ao "mensalão".

Fernando Lugo, no Paraguai, sofreu um impeachment em 2012, e foi afastado, resultado de uma cobertura midiática intensa do discurso "anti-corrupção" durante todos os anos de seu governo, e o processo de julgamento foi antecedido em uma semana por um massacre sangrento às manifestações populares contrárias, episódio que por motivo desconhecido não recebeu quase nenhuma atenção da imprensa. Foi o primeiro neogolpe bem-sucedido na América Latina atual, o segundo foi o golpe no Brasil em 2016, que depôs a presidenta eleita Dilma Rousseff, do Partido dos Trabalhadores, que dava continuidade ao governo Lula ${ }^{26}$.

\section{O teatro da Lava-Jato e o golpe de 2016 no Brasil}

Quando, em 2005, começou a se desenvolver na imprensa a narrativa "anticorrupção" com o objetivo de sabotar a imagem do governo, o golpe fracassou. Em 2009, quando impossibilitou a candidatura de José Dirceu, começou a ser vitorioso. A dimensão simbólica que pintou o Partido dos Trabalhadores como o partido mais corrupto da história do Brasil começou a se expandir e reivindicar outra coisa, muito mais radical: a criminalização da esquerda.

Esta reivindicação, que nunca se explicitou no discurso (até o início das campanhas para a corrida eleitoral de 2018), talvez tenha sido o primeiro sinal de que a política, no

\footnotetext{
${ }^{26}$ Faz-se importante mencionar que Dilma não era a candidata natural do Partido dos Trabalhadores para suceder Lula nas eleições de 2010. Ela substituiu José Dirceu, antigo ministro de Lula, liderança política de uma das alas mais radicais do Partido dos Trabalhadores e ex-guerrilheiro que participou do movimento de resistência armada à Ditadura Militar (1964-1985). Dirceu sofreu um processo lawfare e foi condenado pelo julgamento da Ação Penal 470 (o dito "mensalão"), e a cobertura da imprensa corroborou tanto com a sua massiva queda de popularidade, impedindo-o de se candidatar nas eleições de 2010, quanto com a construção, como aponta Maria Terezinha da Silva (2014) da imagem do Partido dos Trabalhadores como, ao mesmo tempo, um inimigo simbólico que reunia em si toda a corrupção do Brasil e toda a esquerda, comunista ou social-democrata, e até mesmo autodeclarados moderados de esquerda que se opuseram aos governos do PT mas que não compactuaram com as movimentações golpistas.
} 
Estática e fascismo: sobre a formação dos golpes na América Latina

Revista Ensaios, vol. 13, jul-dez de 2018. ISSN 2175-0564.

Brasil, já operava há muito tempo quase exclusivamente no campo da estética ${ }^{27}$.Entretanto, foi com o início da Operação Lava-Jato, em 2014, que se lançou o período mais recente do processo, embora assentado no resultado obtivo com o "mensalão", de 2005. A Lava-Jato, como foi batizada pela Polícia Federal, teve início como uma operação para investigar esquemas de corrupção passiva e ativa envolvendo grandes empreiteiras privadas, como a Odebrecht, a Petrobras, e membros do governo da então presidenta eleita Dilma Rousseff $^{28}$.

Não foi a própria Lava-Jato, por ela mesma, o que chamou a atenção, foi uma peculiar característica que, à medida que ela avançava, fez-se clara: a cobertura intensa dos meios de comunicação de massas. O desenrolar da operação se tornou quase um seriado policial. Ou melhor, se tornou literalmente um seriado policial; José Padilha, o cineasta e roteirista responsável por "Ônibus 174" e pelos dois filmes da sequência "Tropa de Elite", dirigiu uma série, de fato, baseada na Operação Lava-Jato ${ }^{29}$, de nome "O mecanismo".

${ }^{27}$ É claro que isso não significa que este processo não resultou em atividades concretas; resultou, mas, como avaliado nas considerações teóricas iniciais, a estetização da política serve justamente para garantir que tudo o que resulta deste processo seja camuflado e se pareça com o seu oposto.

${ }^{28}$ É válido mencionar que os dois governos petistas contribuíram significativamente para a aglomeração do aparato policial do Estado em volta da pauta "anti-corrupção", concedendo autonomia ao Ministério Público e viabilizando melhoras nas condições de investigação para a Polícia Federal. Todo este conjunto de medidas foi uma faca de dois gumes: ao mesmo tempo em que possibilitou a revelação de vários membros da base do que começava a se mostrar como uma oposição muito tímida dentro do próprio governo, também possibilitou o endurecimento de uma forma policial de Estado que já vinha se mostrando como intenção dos setores mais reacionários do Brasil há tempos. Este segundo gume também cortou pela raíz o Governo Dilma e é diretamente responsável pelo lawfare contra o ex-presidente Lula.

${ }^{29}$ José Padilha é uma figura repleta de questões a serem discutidas. "Ônibus 174", o aclamado documentário de 2002 que remontou a história do sequestro do ônibus da linha 174 no Rio de Janeiro, se contrapõe quase que explicitamente à proposta estética dos dois filmes "Tropa de Elite". O primeiro traça uma cronologia e uma anatomia da marginalização e se propõe a uma discussão política a respeito da origem social da criminalidade, e põe em xeque a estrutura narrativa do vilão e do herói, que permeia o imaginário popular no Brasil quando o assunto é segurança pública; este posicionamento parece se aproximar bastante do que Benjamin entendia como a politização da arte. Os segundos, por outro lado, parecem ter sido construídos em cima do total avesso disto, ou seja, o que Benjamin descreveu como "arte pela arte", glamourizando a violência policial e credibilizando toda uma gama de elementos de marginalização, como tortura e revistas arbitrárias da polícia, no imaginário popular. As crianças do período fundamental, à época, já assistiam cópias do filme e encenavam, como em brincadeiras, entre outras a famosa passagem em que o personagem Capitão Nascimento tortura um sujeito, asfixiando-o com um saco plástico, à procura de informações. Ora, não é isto a mais clara exemplificação do poder de alcance e do funcionamento da estética fascista? A inconsequência desta "arte pela arte" tornou aceitável entre toda uma geração de jovens e adultos o uso sistemático da violência como instrumento político do Estado reacionário e permitiu que esta mesma violência fosse usada como plataforma de campanha do candidato da extrema-direita nas eleições 2018 . O seriado mencionado, "O mecanismo", ficou conhecido por atribuir ao personagem que representava o ex- 
Estática e fascismo: sobre a formação dos golpes na América Latina

Revista Ensaios, vol. 13, jul-dez de 2018. ISSN 2175-0564.

Tornou-se também um filme, que recebeu o título de "Polícia Federal: A lei é para todos", dirigido por alguém que se chama Marcelo Antunez. Estas produções cinematográficas, porém, surgiram certo tempo após a própria Lava-Jato se transformar em uma produção cinematográfica. Tinha, inclusive, um herói ${ }^{30}$. Sérgio Moro, o juiz de primeira instância responsável pelo ordenamento jurídico da Lava-Jato, passou a ser enxergado pela classe média e por boa parte da classe trabalhadora urbana como o grande defensor da moralidade, ao exercer seu papel na operação; neste contexto, boa parte da classe média começou a clamar pela candidatura do juiz nas próximas eleições ${ }^{31}$. Tinha também os vilões: todos os petistas. Como aponta Pereira da Silva (2018), a quantidade de manchetes desfavoráveis à figura de Lula era muito acima do regular. A cada ordem judicial que Sérgio Moro passava, a imprensa cobria incessantemente todos os detalhes, causas e efeitos da medida, até o dia em que, não contentado com simplesmente ter suas ações repercutidas na imprensa de forma aparentemente espontânea, ele mesmo entregou à imprensa $^{32}$ o áudio de uma conversa grampeada inconstitucionalmente entre o expresidente Lula e a então presidenta Dilma. O conteúdo da conversa, que nada tinha de excepcional ou criminoso $^{33}$, repercutiu aos quatro cantos em todos os veículos de comunicação.

Ao mesmo tempo, o ex-presidente Lula era investigado em um processo teatral. Acusado de possuir um apartamento no Guarujá onde foi feita uma reforma paga por uma

presidente Lula (com outro nome) uma fala que, na vida real, foi pronunciada por Romero Jucá, um dos golpistas que movimentou a derrubada de Dilma Rousseff.

30 A revista Veja reconheceu, em uma carta ao leitor publicada em 2019, que sua linha editorial era ativamente favorável à construção da imagem de herói do juiz. A carta, que foi publicada no contexto dos vazamentos evidenciando irregularidades de Sérgio Moro como juiz dos processos julgados com base na operação. Disponível em: https://veja.abril.com.br/politica/carta-ao-leitor-sobre-principios-e-valores/.

${ }^{31} \mathrm{Na}$ época, Sérgio Moro negou envolvimento com a política e disse que nunca mudaria de ideia. Em 2019, entretanto, aceitou o convite de Jair Bolsonaro para liderar o Ministério da Justiça.

32 Posteriormente, o jornal The Intercept Brasil, sob responsabilidade do jornalista norte-americano Glenn Greenwald, vencedor do prêmio Pulitzer, publicou uma série de reportagens embasadas em um documento vazado contendo conversas entre Sérgio Moro, Deltan Dallagnol e outras figuras da Operação Lava-Jato. As conversas comprovam a preocupação política do juiz e do procurador, bem como de outros agentes, e a parceria entre o aparelho judicial e a imprensa. Disponível em: https://theintercept.com/series/mensagenslava-jato/.

${ }^{33} \mathrm{Na}$ época, Dilma havia convidado Lula para chefiar a Casa Civil, em uma tentativa desesperada de fazer com que ele articulasse as alianças para não se concretizar a queda do governo, naquele momento, evidente. Lula já estava sendo investigado no Caso Triplex e, com a nomeação, passaria a responder não mais ao juiz responsável - Sérgio Moro - e sim ao STF, por conta do foro privilegiado. Dilma foi acusada na imprensa de obstrução de justiça. A justiça negou a nomeação de Lula como ministro. 
Estática e fascismo: sobre a formação dos golpes na América Latina

Revista Ensaios, vol. 13, jul-dez de 2018. ISSN 2175-0564.

grande empreiteira em troca de favorecimentos do seu governo à empresa, nem Lula nem ninguém de sua família ou círculo de amigos e partidários havia passado sequer uma noite no apartamento. Não havia nem mesmo qualquer documento que ligasse o apartamento a Lula, muito menos indícios de quaisquer medidas governamentais do governo Lula ou do governo Dilma que favorecessem especialmente a empreiteira responsável pela reforma. Mesmo assim, os veículos de comunicação de massa construíram a narrativa de que Lula era dono do apartamento e havia ocultado o patrimônio ${ }^{34}$. Neste cenário, todos os aspectos da vida de Lula passaram a ser detalhadamente investigados pela Polícia Federal e estas investigações receberam talvez a maior cobertura midiática que qualquer outra operação policial na história recente do Brasil. Moro ordenava e a Polícia Federal entrava na casa de Lula, nas casas de seus familiares, tendo certa vez apreendido até mesmo um tablet que pertencia a um de seus netos de poucos anos de idade. Mesmo aos mais de 70 anos e sem nunca ter se negado a depor, Lula se viu, certo dia, às 6h da manhã, sendo levado para depor em condução coercitiva pela Polícia Federal na escolta de mais de duzentos policiais federais.

A imagem repercutiu na imprensa de maneira que era cansativo ler ou assistir aos jornais. Também repercutiam mais ou menos no mesmo período de tempo as imagens de manifestações da classe média contra o Governo Dilma. Algumas coisas dentre muitas chamavam a atenção do espectador mais atento: os manifestantes não pareciam manifestar coisa alguma ${ }^{35}$ a não ser palavras de ordem direcionadas contra "a corrupção", como se isto fosse não um substantivo abstrato e sim uma pessoa; a derrubada de Dilma era pregada pelos manifestantes como um ato de mudança ou de revolução $o^{36}$.

\footnotetext{
${ }^{34}$ Uma ferramenta denominada "Manchetômetro", produzida pelo Laboratório de Estudos de Mídia e Esfera Pública da Universidade Estadual do Rio de Janeiro, possibilita medir a quantidade de manchetes favoráveis, desfavoráveis e a curva de crescimento ou decaimento dessa quantidade ao longo do tempo, a partir da pesquisa por palavras-chave como "Lula". Os dados demonstram que os dois períodos de pico das manchetes desfavoráveis à figura de Lula ocorreram em 2016, à época do golpe de Estado contra o governo Dilma, e em 2018, à época das eleições presidenciais. Disponível em: http://www.manchetometro.com.br/.

${ }^{35}$ Pareciam, pelo contrário, participar de uma festa. Havia cerveja, fantasias carnavalescas, grandes bonecos como os de Olinda e, em certa ocasião, uma instituição privada forneceu champanhe para os "manifestantes". ${ }^{36}$ Os mais inflamados, de fato, clamavam pela intervenção militar que chamavam de "revolução".
} 
Estática e fascismo: sobre a formação dos golpes na América Latina

Revista Ensaios, vol. 13, jul-dez de 2018. ISSN 2175-0564.

Toda esta movimentação, se analisada em seus aspectos individuais, aparenta ser bastante caótica ${ }^{37}$. Todavia, uma análise coordenada de todos eles é capaz de perceber que é simplesmente impossível que uma orquestração não tenha sido implementada. E, em especial, que esta orquestração foi estética. O governo Dilma, já asfixiado e congelado, não conseguia construir narrativa alguma. Dilma parece ter entendido esta questão quando, pouco tempo antes de ser afastada do governo, organizou eventos oficiais com cobertura de veículos da imprensa alternativa para reafirmar seu compromisso com as massas trabalhadoras e camponesas ${ }^{38}$, mas a compreensão chegou tarde demais e não houve tempo para recuperar todo o prejuízo.

Durante todo o período de 2005 até 2016, quando o auge do processo foi atingido, os meios de comunicação de massa semearam uma narrativa completa, uma ficção minuciosamente bem construída, com heróis e vilões, alívios cômicos, reviravoltas e clímaces catárticos. Todos os elementos narrativos apontavam o Partido dos Trabalhadores como representante de toda a esquerda ${ }^{39}$ e, também, como o representante de toda a corrupção existente; com uma peça ligada à outra, o discurso antipetista tomou ares de uma concreta paranoia anticomunista. Os heróis, claro, eram qualquer um que se opusesse ao PT.

O cortejo aos vencedores se expunha, agora claro para a Tradição dos Oprimidos. Na mais recente entrevista do ex-presidente Lula, concedida a dois veículos de imprensa ${ }^{40}$ de dentro da prisão após uma extensa batalha judicial, ele admitiu que o maior erro do seu governo foi não ter implementado a regulamentação dos veículos de comunicação, medida

\footnotetext{
${ }^{37}$ Também não por acaso. No livro "Guerras híbridas: das revoluções coloridas aos golpes", Andrew Korybko (2018) ressalta a importância da aparência de caos na execução do neogolpismo e explica a noção de "caos criativo", originada nos documentos de estratégia política militar que formam as diretrizes da política externa dos Estados Unidos.

${ }^{38}$ Compromisso que, mesmo que de fato existisse, estava já deteriorado desde o final do primeiro mandato de Dilma, com a apropriação da vanguarda das Jornadas de Junho de 2013 pela direita e extrema-direita e a consequente guinada do governo a posicionamentos menos reformistas para renovar a base de aliados em outros setores que não a esquerda.

${ }^{39}$ Isto refletiu mais radicalmente em discursos inflamados de certos setores populares que passaram a enxergar o PT, literalmente, como uma organização mundial com plano de "dominação comunista". ${ }^{40} \mathrm{Um}$ deles com claro posicionamento tendente à esquerda e o outro de tradição conservadora, porém, com linha editorial disfarçada de plural.
} 
Estática e fascismo: sobre a formação dos golpes na América Latina

Revista Ensaios, vol. 13, jul-dez de 2018. ISSN 2175-0564.

que acabaria com o monopólio dos veículos tradicionais no Brasil. Lula parece ter entendido muito bem no que consistiu o processo por completo.

Durante os treze anos de governo do Partido dos Trabalhadores, toda a imprensa hegemônica era oposição. A dimensão estética da política foi, de certa forma, bastante subestimada pela coalizão da esquerda. É claro que, ao início do primeiro mandato, Lula detinha uma invejável popularidade e, ao final, esta era maior ainda - terminou o mandato com $87 \%$ de aprovação, segundo o Ibope. Talvez isto, naquele momento, tivesse servido de prova final, para eles, da insuficiência dos meios de comunicação de massas em se opor a um governo progressista, talvez a esperança de que os avanços sociais fossem tão impactantes que ofuscariam o discurso reacionário da imprensa tivesse sido o principal fator que levou à adoção da via burguesa e institucional que defendia a "liberdade de imprensa". De fato, Pereira da Silva (2018) comenta que há uma relação entre as consecutivas vitórias da esquerda e os avanços sociais, demonstrando a capacidade que estes projetos têm de ganhar o voto popular. Tal liberdade, entretanto, nunca incluiu os veículos da imprensa alternativa; no entanto, também aponta a infeliz surpresa que foi a constatação prática de que, mesmo assim, ainda restavam outras insuficiências. A história que foi construída, sua narrativa, ao longo de todos os anos de governo de Lula e Dilma foi a história da imprensa burguesa. Parece que, afinal de contas, Lula, Dilma e todos os trabalhadores e trabalhadoras rurais e do campo que se representam no projeto de governo deles, continuavam sendo os perdedores do conflito da luta de classes, e os aparentes perdedores, na verdade, ainda não haviam cessado de vencer. A capacidade de alcance dos meios de comunicação de massas foi negligenciada ao ponto de se tornar imperceptível um processo visível de transferência da política para o campo estético.

\section{Considerações práticas sobre fascismo, estética e política}

No prefácio de uma das edições do texto "O 18 Brumário de Luís Bonaparte", um dos mais precisos e completos de Marx, HebertMarcuse(1998) explica que aquilo que o autor relatava ao calor da Revolução Francesa de 1848 e do golpe de Estado de Luís 
Estática e fascismo: sobre a formação dos golpes na América Latina

Revista Ensaios, vol. 13, jul-dez de 2018. ISSN 2175-0564.

Bonaparte no segundo ano de seu mandato presidencial, na verdade, era uma experiência concreta do que, naquele período, se anunciava que aconteceria como processo de desenvolvimento do capitalismo. O "longo casamento", como Zizek definiu a relação entre capitalismo e democracia liberal, estava chegando ao fim e aquele episódio foi o prenúncio. Os aparelhos institucionais de formação política da democracia liberal passaram a funcionar como frequentes ferramentas de manutenção do que a própria democracia liberal repudia (pelo menos em tese).

O que Marx (1998) percebeu e documentou no texto, foi também, além disso, uma característica bastante profunda da própria forma de democracia liberal que já começava a entrar em crise em seus próprios termos: o modelo de democracia moderna constitucional, que rege a maioria dos Estados contemporâneos, confere um poder que é somente virtual à assembleia legislativa. A assembleia, em tese, representa o conjunto de pautas de toda a população do país; porém, ela é eleita em partes, e cada fração do país elege uma parte. O presidente, por outro lado, é eleito, em tese, pelo país. Esta contradição é concreta, mas também simbólica. Como chefe de Estado, o presidente concentra uma maior quantidade de poder decisivo em relação à assembleia legislativa (ele, por exemplo, pode sancionar ou vetar propostas votadas em assembleia), e o parlamento concentra um poder manifestado de forma indireta sobre as decisões. Paralelamente, na dimensão simbólica, o presidente tem o poder de contrariar a assembleia deliberadamente, e a assembleia não tem o poder de contrariá-lo diretamente, mesmo que represente com mais concretude, em tese, os interesses de maiores parcelas do país como um todo.

Walter Benjamin (1985), bem depois de Marx, também parece ter compreendido este tipo de crise já no seu estágio mais avançado. Em "A obra de arte na era de sua reprodutibilidade técnica", estabelece uma comparação análoga entre os elementos do cinema e os elementos da política. Argumenta que a reprodutibilidade técnica da arte possibilitou à nova forma dos meios de comunicação de massas um feito antes impossível: levar a fala do político para fora do parlamento, em direção à difusão massiva. Tornou-se irrelevante para o presidente a defesa de seus posicionamentos perante o parlamento. Com os meios de comunicação de massas, ele pode contar sua história às massas, e pouco lhe 
Estática e fascismo: sobre a formação dos golpes na América Latina

Revista Ensaios, vol. 13, jul-dez de 2018. ISSN 2175-0564.

importa se o parlamento é concordante ou se deixa de ser. O resultado disto é, em última instância, a crise da democracia liberal que engole sua própria forma, e substitui o presidente por ditador. O papel do político desta nova configuração de formação, isto é, a fascista, se trata não só de se exibir aos veículos de comunicação de massa, mas também de, antes, selecionar $o$ que será exibido.

Duas outras observações de Marx (1998) e Benjamin (2005), respectivamente, são bastante relevantes para esta discussão, e aqui se farão presentes:

O estado de sítio de Paris foi a parteira que ajudou a Constituinte no trabalho de parto da sua criação republicana. Mesmo que a Constituição mais tarde tenha sido eliminada pela baioneta, não se pode esquecer que foi igualmente pela baioneta, mais precisamente, pela baioneta voltada contra o povo, que ela teve de ser protegida já no ventre materno e foi pela baioneta que ela teve de ser trazida ao mundo.

A tradição dos oprimidos nos ensina que o 'estado de exceção' no qual vivemos é a regra. Precisamos chegar a um conceito de história que dê conta disso. Então surgirá diante de nós nossa tarefa, a de instaurar o real estado de exceção; e graças a isso, nossa posição na luta contra o fascismo tornar-se-á melhor. A chance deste consiste, não por último, em que seus adversários o afrontem em nome do progresso como se este fosse uma norma histórica. - $\mathrm{O}$ espanto em constatar que os acontecimentos que vivemos 'ainda' sejam possíveis no século $\mathrm{XX}$ não é nenhum espanto filosófico. Ele não está no início de um conhecimento, a menos que seja o de mostrar que a representação da história de onde provém aquele espanto é insustentável.

Quando Marx observou a contradição inerente ao próprio nascimento da democracia liberal, o que levou em consideração foi um cenário em que o estado de sítio era um recurso frequentemente utilizado para que se fizesse a manutenção da ordem burguesa e de suas relações de produção. Benjamin, por outro lado, observou em seu tempo um outro estágio de desenvolvimento desta contradição, onde o estado de sítio já não é mais uma ferramenta utilizada frequentemente, ele se tornou a própria configuração da ordem burguesa. Esta ordem burguesa que se firma sobre o estado de "constante exceção" necessita, como pontuado anteriormente, de uma concepção da história que favoreça seu avanço.

O que mais pode ter sustentado o processo de endurecimento do Estado policial que se concretizou com a Operação Lava-Jato senão a concepção histórica burguesa, contando 
Estática e fascismo: sobre a formação dos golpes na América Latina

Revista Ensaios, vol. 13, jul-dez de 2018. ISSN 2175-0564.

a narrativa oficial difundida através dos meios de comunicação de massa? Não cortejou as vitórias incessantes dos setores mais reacionários alinhados à narrativa do golpe? E a difusão das perseguições políticas nos mesmos meios de comunicação não pôs em xeque também a formação política do Estado de Direito quando legitimou estas irregularidades no imaginário popular? Não é de se espantar que a maior conquista deste processo que foi o golpe de Estado de 2016 no Brasil tenha sido a eleição de um fascista - qual outro tipo de político poderia significar a concretude mais radical de um processo que se debruçou quase integralmente na estética fascista e no seu modo de operação política?

O que antes consistia apenas em uma reivindicação aparentemente impossível, tornou-se possível para o espanto dos que se recusavam a enxergar o processo inteiro: a esquerda foi criminalizada, finalmente. O estado de sítio, tão pedido a todo o tempo pelos meios de comunicação de massa, foi não só imposto, mas eleito. Eleito por uma boa parte da classe trabalhadora que vinha elegendo, até poucos anos antes, governos de esquerda.

Benjamin (1985), ao final do ensaio sobre a reprodutibilidade técnica, também observa outro aspecto importantíssimo da estética fascista, isto é, que ela desemboca, necessariamente, na guerra, pois não há outra via de manter-se funcionando uma operação artística da política, isto é, o conjunto de ações políticas que fora transferido para o campo da estética. $\mathrm{O}$ fascismo promete às classes trabalhadoras algo que não pode cumprir, a saber, a concretização de suas reivindicações; porém, ao permitir que estas classes expressem estas reivindicações através da simbologia política que ele engendra, ele também faz avançar o reconhecimento da sua principal contradição: as classes trabalhadoras começam a perceber que ele não vai concretizar estas reivindicações. A melhor maneira de mantê-la sob suas rédeas é, portanto, mobilizando-a. Como não pode mobilizá-la para garantir, de fato, as reivindicações, só resta a guerra - que não por acaso é fundamentada sobre a mesma lógica do herói e do vilão - como canalização de todas estas necessidades de vitória, e também pela guerra são movimentados todos os recursos técnicos paralisados pela ardente contradição deste estágio do capitalismo.

Não é de se espantar que o fascista eleito no Brasil frequentemente endosse a narrativa da historiografia burguesa construída em tempo real sobre a Venezuela. Há 
Estática e fascismo: sobre a formação dos golpes na América Latina

Revista Ensaios, vol. 13, jul-dez de 2018. ISSN 2175-0564.

declarações públicas do sujeito insinuando que enviaria ajuda militar aos Estados Unidos em uma possível intervenção militar contra o governo democraticamente eleito de Nicolás Maduro. A onda de políticos da extrema-direita que, no Brasil, elegeram-se na "cauda do vestido de noiva" de Bolsonaro endossam tanto a guerra contra a Venezuela como a guerra aos pobres e negros dentro das favelas e a guerra aos camponeses e indígenas no campo. Todos estes elementos são englobados dentro da figura da esquerda, do PT, do inimigo a ser combatido. Esta é a forma de mobilização das massas que o neofascismo brasileiro encontrou. "Mira na cabecinha e...", declarou publicamente o governador eleito do Rio de Janeiro, cuja campanha eleitoral envolveu um comício em que se quebrou ao meio a placa de rua com o nome de Marielle Franco. Há um motivo pelo qual a violência sistemática é a plataforma de apelo deste grupo: a estetização da política necessita da construção imagética de um único inimigo. Aqui no Brasil, este inimigo ainda não é o judeu.

\section{Referências:}

BENJAMIN, W. A obra de arte na era de sua reprodutibilidade técnica. In: Magia e técnica, arte e política: ensaios sobre literatura e história da cultura. Tradução: ROUANET, S. P. São Paulo: Editora Brasiliense, 1985.

. Para uma crítica da violência. In: Escritos sobre mito e linguagem.São Paulo: Editora 34, 2011.

. Teses sobre o conceito de história. In: LÖWY, M. Walter Benjamin: aviso de incêndio - uma leitura das teses sobre o conceito de história.Tradução das teses: GAGNEBIN, J. M.; MÜLLER, M. L. São Paulo: Boitempo Editorial, 2005.

BRUCKMANN, M. América Latina y la disputa global por recursos naturales: estratégias hegemónicas y contra-hegemónicas. In:América Latina EnMovimiento, v. 466, p. 20-25. Quito: 2011.

HOBSBAWM, E. Revolucionários. Tradução: CARLOS, J; GARCIA, V; SAGGIORO GARCIA, A. Rio de Janeiro: Paz e Terra, 1982.

HOBSBAWM, E. Viva larevolución: a era das utopias na América Latina. Tradução: MAIA SOARES, P. São Paulo: Companhia das Letras, 2017. 
Estática e fascismo: sobre a formação dos golpes na América Latina

Revista Ensaios, vol. 13, jul-dez de 2018. ISSN 2175-0564.

JAPIASSÚ, H; MARCONDES, D. Dicionário básico de Filosofia. Rio de Janeiro: Jorge Zahar Ed., 1996.

KORYBKO, A. Guerras híbridas: das revoluções coloridas aos golpes. Tradução:ANTUNES, T. São Paulo: Expressão Popular, 2018.

LANDER, E. Venezuela: a busca de um projeto contra-hegemônico. In: Hegemonias e emancipações no século XXI. São Paulo: CLACSO, 2005.

LÓPEZ MAYA, M. El golpe de Estado del 11 de abril en Venezuela y sus causas. In: Revista Sociedad y Economía, no 3, p. 7-18. Cali: 2002.

LÓPEZ MAYA, M; LANDER, E. Venezuela, golpe y petróleo. In: Observatorio Social de América Latina, $\mathrm{n}^{\circ}$ 7. Buenos Aires: 2002.

MARX, K. O 18 Brumário de Luís Bonaparte. Tradução: SCHNEIDER, N. São Paulo: Boitempo, 2011.

MARX, K; ENGELS, F. O manifesto do Partido Comunista. Tradução: PINA, A. São Paulo: Boitempo, 1998.

PEREIRA DA SILVA, F. O fim da Onda Rosa e o neogolpismo na América Latina. In: Revista Sul-Americana de Ciência Política, v. 4, nº 2, p. 165-178. Pelotas: 2018.

RIBEIRO, E; CARREIRAO, Y; BORBA, J. Sentimentos partidários e antipetismo: condicionantes e covariantes.In: Opin. Publica, v. 22, n. 3, p. 603-637,Campinas: 2016.

TEREZINHA DA SILVA, M. Acontecimento: evocando sentidos, provocando ações uma análise do "Mensalão". In: Intexto, v. 00, n 30, p. 72-92. Porto Alegre: 2014.

THALHEIMER, A. Sobre o fascismo. Salvador: CVM, 2010.

ZIZEK, S. Violência. Tradução: SERRAS PEREIRA, M. São Paulo: Boitempo, 2014. 